\title{
PENGARUH KUALITAS PENGUNGKAPAN INFORMASI TERHADAP VOLUME PERDAGANGAN SAHAM DAN RETURN SAHAM STUDI EMPIRIS PADA PERUSAHAAN LQ-45 DI BEI
}

\author{
Maristiana Ayu \\ Dosen Fakultas Ekonomi Universitas Sang Bumi Ruwa Jurai B. Lampung \\ Jln. Imam Bonjol No. 468 Langkapura B. Lampung \\ Telp. (0721)257838,265734, Fax.(0721) 257838, HP. 081369675525 \\ Email: maristianaayu@yahoo.co.id
}

\begin{abstract}
The influence of disclosure and time accuracy value is as an indicator to determine information expression quality degree. The completement of disclosure which has a high index and time accuracy is faster after auditing. Its give an instruction to the investors, that is a quality information. It will influence share trade volume and share return. The purpose of this research is to exam the quality of information expression toward share -trade volume and share-return at LQ-45 Company in Global Crisis Context since 2008 until 2011. The researcher conducts the supervision about the circulation of share for 10 days: 5 days before and 5 days after the expression. To analysys data in this research uses Multiple Linear Regresion Analysis Into two regression model to know the influence of Information expression quality toward share-trade volume and share-return.

The result of this reearch indicates that statistically expression quality which is seen by disclosure fulfilment and time accuracy of monetary report has a siqnificant influence $<0,05$ toward share-trade volume and share-return. Disclosure fulfilment influence positively toward share-trade volume. Seeing on time accuracy, expression quality which influence share-return has a siqnificant influence. On the other hand disclosure fulfilment has a negative influence toward share-return. All result indicate that information expression quality which is shown in annual report is not an important information in giving a good signal to take a decision for investors to invest, especially in global crisis context.
\end{abstract}

Key word : Information Expression Quality, Share-trade volume and share-return

\section{LATAR BELAKANG}

Krisis ekonomi global merupakan peristiwa di mana seluruh sektor ekonomi pasar dunia mengalami keruntuhan dan mempengaruhi sektor-sektor lainnya, termasuk di Indonesia. Negara adidaya yang memegang kendali ekonomi pasar dunia juga tidak terlepas mengalami keruntuhan besar dari sektor ekonominya. Bangkrutnya Lehman Brothers yang terjadi pada bulan September 2008 langsung mengguncang bursa saham di seluruh dunia. Bursa saham di kawasan Asia seperti di Jepang, Hongkong, China, Australia, Singapura, 
India, Taiwan dan Korea Selatan mengalami penurunan drastis mencapai 7 - 10 persen. Begitu juga bursa saham di kawasan Timur Tengah, Rusia, Eropa, Amerika Selatan dan Amerika Utara tak terkecuali di AS sendiri, para investor di bursa Wall Street mengalami kerugian besar, termasuk pasar modal Indonesia dimana sebagian besar investor pasar modal Indonesia adalah investor asing (Nuh, 2008).

Besarnya investor asing di Indonesia dan perilaku investor dalam menjual saham yang meningkat tajam menyebabkan IHSG mengalami penurunan, hal ini mendorong peran Bursa Efek Indonesia untuk melakukan penghentian perdagangan saham (suspend) karena penurunan indeks IHSG yang besar yakni mencapai 10,30\%.

Fundamental ekonomi Indonesia yang menguat membuat investor global menilai Indonesia sebagai safe heaven. Arus dana asing (hot money) mengalir deras ke pasar saham dan Surat Utang Negara (SUN) sehingga cadangan devisa membengkak, rupiah menguat dan IHSG mencatat rekor tertinggi di level 4.132,78 di akhir tahun 2010. Krisis ekonomi nampaknya belum selesai dan mulai dirasakan di Indonesia sejak awal September 2011 sebagai dampak dari krisis utang di Eropa dan Amerika Serikat akibat gejolak pasar modal dan pasar uang. Kenyataannya pada akhir tahun pasar saham indonesia memberikan hasil yang menggembirakan dengan terjadinya kenaikan IHSG sebesar 3\% dibandingkan tahun 2010.

Dampak krisis keuangan global sejak tahun 2008 an mengakibatkan para investor dan kreditur sangat berhati - hati dalam menginvestasikan modalnya untuk mengantisipasi risiko yang akan terjadi, termasuk menelaah secara teliti laporan keuangan yang dimiliki suatu perusahaan untuk mengetahui kelangsungan hidup perusahaan tersebut. Para Investor menilai, diantaranya : bagaimana sistem manajemen melakukan pengungkapan yang lebih berkualitas dalam laporan keuangan, menjelaskan kinerja perusahaan secara keseluruhan dan informasi lainnya dapat dipahami, dipercaya, relevan dan transparan. Kualitas yang memadai dapat ditunjukkan dari pengungkapan, karena :

1. Pengungkapan laporan keuangan oleh perusahaan merupakan accountability perusahaan kepada para penyedia modal yang berada diluar perusahaan dan memudahkan alokasi sumberdaya untuk pemanfaatan yang paling produktif. Pengungkapan laporan keuangan dapat dilakukan dalam bentuk penjelasan mengenai kebijakan akuntansi, sehingga informasi yang diungkapkan oleh perusahaan dapat dipahami dan tidak menimbulkan salah interprestasi. 
2. Kualitas informasi keuangan, tercermin pada sejauh mana luas pengungkapan laporan dan tingkat kelengkapan pengungkapan yang di terbitkan oleh perusahaan. Pengungkapan dalam laporan tahunan merupakan sumber informasi untuk mengambil keputusan investasi. Keputusan investasi sangat tergantung dari kualitas dan luas pengungkapan yang terdapat dalam laporan tahunan.

3. Tingkat pengungkapan yang lengkap, luas dan ketepatan waktu penyampaian informasi keuangan adalah menentukan kualitas dalam pengungkapan informasi keuangan (Buzby,1975 ; Baret,1976 ; Whittred,1980 dan Imhoff,1992 dalam Andrian, 2010).

Beberapa penelitian menguji reaksi investor terhadap publikasi laporan keuangan dan hasilnya menunjukkan adanya pengaruh kandungan informasi keuangan terhadap volume perdagangan dan harga saham (Holthausen dan Verrecchia,1990 ; Kim dan Verrecchia, 1991; Jennings, 1990 ; Bamber, 1986; Husnan, Hanafi dan Wibowo, 1995 dalam Anwar, 2010 ; Bessembinder dan Seguin, 1993 dalam Michael Gruning, 2011 ; Medeiros, 2003 dan Mouselli, 2009 dalam Anwar, 2010). Penelitian Leuz dan Verrecchia (1999) yang di teliti kembali Heflin , Bushee, Noe (1999) dan diperkuat penelitian Grinning (2011) menyimpulkan bahwa kualitas pengungkapan yang tinggi mengurangi asymetri informasi, sehingga akan meningkatkan likuiditas pasar yang berdampak positip pada volume perdagangan saham.

Penelitian yang dilakukan Bushee, Brian J \& Noe (2000) menyimpulkan bahwa terdapat hubungan positif antara volatilitas harga dan omset saham atau pergerakan harga saham setelah adanya pengungkapan, sehingga mengurangi terjadinya asymetri informasi. Namun penelitian yang dilakukan di Indonesia melihat kualitas informasi yang diproksikan dalam tingkat kelengkapan seperti oleh Junaedy (1995) menunjukkan bahwa pengungkapan informasi yang komprehensif atau lengkap berpengaruh tidak begitu kuat atau kecil terhadap aktivitas atau volume perdagangan dan tidak berpengaruh terhadap return saham. Sedangkan penelitian suharli (2008) melihat return terhadap ketepatan waktu menunjukkan bahwa return saham tidak berpengaruh terhadap ketepatan waktu, namun penelitian Priyastiwi (2000) dan Wirakusuma (2008) menunjukkan bahwa ketepatan waktu berpengaruh terhadap kandungan kualitas informasi laba akuntansi atau return saham.

Berdasarkan hal tersebut peneliti ingin menguji kembali mengenai pengaruh kualitas pengungkapan dengan melihat tingkat kelengkapan pengungkapan(disclosure) dan ketepatan waktu terhadap aktivitas volume perdagangan saham dan return saham, atau melihat apakah 
kualitas pengungkapan masih mempunyai pengaruh terhadap pergerakan volume perdagangan saham dan return saham terutama pada masa krisis global yang terjadi di tahun 2008 - 2011 pada bursa efek di Indonesia, dimana masa tersebut khususnya Indonesia memiliki tingkat pergerakan saham yang dinilai cukup baik meskipun mengalami sedikit pengaruh terhadap krisis global.

Penelitian ini mempunyai beberapa tujuan: (1) menguji secara empiris apakah kualitas pengungkapan informasi berpengaruh terhadap volume perdagangan saham (2) menguji secara empiris apakah kualitas pengungkapan informasi berpengaruh terhadap return saham. Hasil studi ini diharapkan: (1) kontribusi pada pengembangan teori yang berkaitan dengan pengaruh kualitas pengungkapan terhadap volume perdagangan dan return saham dipasar modal (2) memberikan informasi kepada emiten tentang respon investor atas kelengkapan pengungkapan dan ketepatan waktu pengungkapan sehingga emiten dapat melakukan koreksi agar dapat memenuhi harapan investor. Dalam penelitian ini, peneliti membatasi permasalahan yaitu:(1) faktor lain yang dapat mempengaruhi kondisi masa krisis global yaitu fundamental ekonomi seperti kondisi finansial, pembiayaan ekonomi, dan pertumbuhan ekonomi dianggap bersifat tetap / konstan.(2) penelitian dilakukan pada perusahaan yang sahamnya listed di bursa efek,dan memiliki tingkat kapitalisasi pasar yang tinggi yaitu perusahaan yang di kelompokkan dalam LQ-45.(3) kualitas pengungkapan yang digunakan dalam penelitian ini diproxikan pada kelengkapan pengungkapan (disclosure), yaitu pengungkapan wajib dan pengungkapan sukarela serta ketepatan waktu pengungkapan informasi. 


\section{TINJAUAN PENELITIAN DAN PENGEMBANGAN HIPOTESIS}

\subsection{Kualitas Pengungkapan}

Kualitas Pengungkapan dalam laporan tahunan perusahaan dikenal dengan berbagai konsep, antara lain : kecukupan (adequacy) (Buzby, 1975), kelengkapan (comprehensiveness) (Barret, 1976), informatif (informativeness) (Alford et al, 1993), dan tepat waktu (time lines) (Courtis, 1976; Whittred, 1980). Imhoff (1992) menunjuk tingkat kelengkapan sebagai karakteristik kualitas pengungkapan, Menurut Singhvi dan Desai (1971) : kelengkapan (completeness), akurasi (accuracy), dan keandalan (reliability) sebagai karakteristik kualitas pengungkapan. Indikator empiris kualitas ungkapan tersebut berupa indeks pengungkapan (disclosure index) yang merupakan rasio (ratio) antara jumlah elemen/item informasi yang dipenuhi dengan jumlah elemen yang mungkin dipenuhi. Makin tinggi angka indeks pengungkapan, maka makin tinggi kualitas pengungkapan (Andrian , 2010).

Kualitas dalam pengambilan keputusan dipengaruhi oleh kualitas pengungkapan perusahaan yang diberikan melalui laporan tahunan (annual report). Agar informasi yang disajikan dalam laporan keuangan dapat di pahami dan tidak menimbulkan salah interpretasi, maka penyajian laporan keuangan harus disertai dengan pengungkapan yang cukup (adequate disclosure).

\subsection{Kelengkapan Pengungkapan (disclosure) Laporan Keuangan}

Kelengkapan (comprehensiveness) merupakan suatu bentuk kualitas dimana menurut Imhoff dalam Na'im dan Fuad (2000) dalam Binsar H. Simanjuntak dkk (2004), kualitas tampak sebagai atribut-atribut yang penting dari suatu informasi. Namun kualitas akuntansi masih memiliki makna ganda (ambiguous), dimana banyak penelitian yang menggunakan index of disclosure methodology mengemukakan bahwa kualitas kelengkapan pengungkapan laporan keuangan dapat di ukur dan digunakan untuk menilai manfaat potensial dari isi suatu laporan keuangan tahunan. Tingginya kualitas informasi akuntansi sangat berkaitan dengan tingkat kelengkapan pengungkapan laporan keuangan. 


\subsection{Ketepatan Waktu}

Ketepatan waktu dalam penyampaian informasi keuangan sangat berpengaruh terhadap kualitas informasi keuangan, karena informasi yang tercantum tersebut masih bersifat baru dan tidak out of date. Pernyataan ini dapat dijadikan pedoman bagi investor untuk menilai bahwa laporan keuangan dapat digunakan sebagai dasar pengambilan keputusan. McGee, dalam Sulistyo ( 2010) dalam RS. Sidauruk (2012) menyatakan bahwa "rentang waktu antara tanggal laporan keuangan perusahaan dan tanggal ketika informasi keuangan di umumkan ke publik berhubungan dengan kualitas informasi keuangan yang dilaporkan". Selain mengenai kualitas, ketepatan waktu juga menentukan transparansi laporan keuangan. Apabila perusahaan terlambat dalam mempublikasikan laporan keuangannya, besar kemungkinan transparansi dari laporan tersebut tidak akan baik.

Akumulasi, peringkasan, dan penyajian selanjutnya informasi akuntansi harus dilakukan secepat mungkin untuk menjamin tersedianya informasi di tangan pemakai informasi akuntansi tersebut. Ketepatan waktu juga menunjukkan bahwa laporan keuangan harus di sajikan pada kurun waktu yang teratur untuk memperlihatkan perubahan keadaan perusahaan yang pada gilirannya mungkin akan mempengaruhi prediksi dan keputusan pemakai. Sesuai dengan peraturan X.K.6 yang diterbitkan Bapepam, penyampaian laporan keuangan tahunan yang telah di audit dikatakan tepat waktu apabila diserahkan sebelum atau paling lambat pada akhir bulan ke empat setelah tanggal laporan keuangan tahunan perusahaan publik tersebut.

\subsection{Aktivitas Volume Perdagangan (Trading Volume Activity/TVA)}

Volume perdagangan merupakan bagian yang diterima dalam analisis teknikal. Kegiatan perdagangan dalam volume yang sangat tinggi di suatu bursa, akan di tafsirkan sebagai tanda pasar akan membaik. Peningkatan volume perdagangan saham yang dibarengi dengan peningkatan harga, merupakan gejala yang semakin kuat akan kondisi yang bullish (Neni dan Mahendra, 2004, dalam Munawarah, 2009).

Volume perdagangan saham dapat digunakan oleh investor untuk melihat apakah saham yang dibeli tersebut merupakan saham yang aktif di perdagangkan di pasar (Neni dan Mahendra, 2004). Saham yang aktif perdagangannya sudah pasti memiliki volume perdagangan yang besar dan saham dengan volume yang besar akan menghasilkan return saham yang tinggi (Tharun, 2000). Menurut Husnan, dkk (1996) untuk mengukur kegiatan 
perdagangan saham melalui indikator TVA (Trading Volume Activity) dapat digunakan untuk melihat apakah investor individual menilai laporan keuangan informatif, dalam arti apakah informasi tersebut membuat keputusan perdagangan di atas keputusan perdagangan normal. Sedangkan menurut Neni dan Mahendra (2004), perubahan volume perdagangan saham di pasar modal menunjukkan aktivitas perdagangan saham di bursa dan mencerminkan keputusan investasi oleh investor.

Informasi sangat berperan penting dalam pengambilan keputusan investasi bagi para investor. Adanya publikasi laporan keuangan menjadi informasi relevan yang dapat digunakan sebagai dasar keputusan dalam melakukan investasi di pasar modal. Disamping itu tentunya akan berdampak positif, sehingga pergerakan nilai perdagangan saham akan meningkat atau volume perdagangan menjadi besar.

Konsep diatas sesuai dengan penelitian Chang, Most, dan Brain (1983) yang menunjukkan pentingnya laporan keuangan tahunan perusahaan sebagai suatu informasi untuk keputusan investasi. Penelitian yang dilakukan Beaver (1968) dan dikembangkan kembali oleh Kim and Verrecchia (1990) dalam Bandi dan Jogiyanto (1999) menyatakan informasi akuntansi mempunyai kandungan informasi dipasar modal. Kandungan informasi tersebut terwujud dari laporan annual report atau laporan tahunan yang dikeluarkan oleh perusahaan yang menggambarkan tentang kinerja perusahaan secara komprehensif, baik mengenai informasi keuangan maupun non keuangan.

Pengungkapan (disclosure) yang dilakukan perusahaan melalui laporan tahunan secara komprehensif (lengkap) dan tepat waktu menunjukkan adanya pengungkapan informasi yang berkualitas, sehingga akan menjadi rujukan bagi investor maupun calon investor untuk memutuskan berinvestasi pada suatu perusahaan. Pengungkapan ini akan berdampak pada pergerakan saham yang di perdagangkan atau likuiditas saham serta return saham.

Berdasarkan uraian diatas maka dapat dikembangkan suatu kerangka pemikiran sebagai berikut :

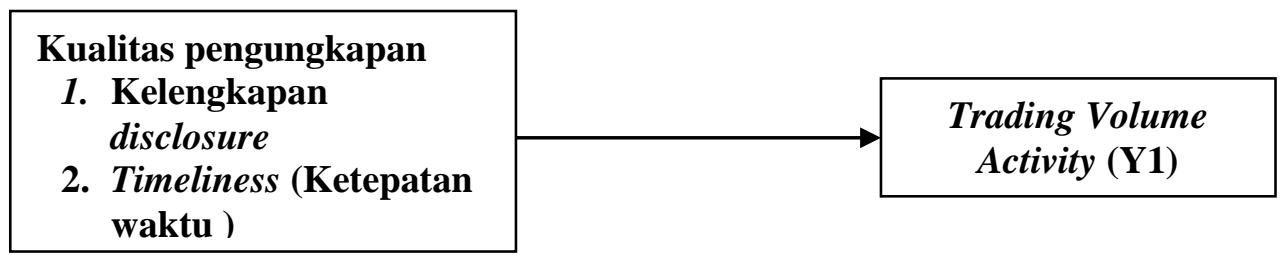


Kualitas pengungkapan

1. Kelengkapan

disclosure

2. Timeliness (Ketepatan

waktu )

\subsection{Pengaruh Kelengkapan disclosure terhadap Trading Volume Activity (TVA)}

Beberapa penelitian menunjukkan bahwa pengungkapan informasi sebelum pengumuman mempunyai reaksi yang berbeda dibandingkan setelah adanya pengumuman terhadap pergerakan volume perdagangan. Penelitian Jennings(1990) dan Bamber (1986), menguji apakah para investor bereaksi terhadap laporan keuangan yang di publikasikan sehingga berdampak adanya pengaruh kandungan informasi terhadap volume perdagangan. Penelitian yang dilakukan Peter D. Wysocki (2000), menguji kembali penelitian Kim and Verrecchia (1991) yang menunjukkan bahwa pengumuman laba berpengaruh secara positif terhadap volume perdagangan dibandingkan sebelum adanya pengumuman. Penelitian Dedi junaidi (2005), melihat perbedaan tingkat pengungkapan informasi baik secara komprehensif (lengkap) dan tidak secara komprehensif (tidak secara lengkap). Hasilnya menunjukkan bahwa pengungkapan yang komprehensif (lengkap) berpengaruh positif terhadap volume perdagangan saham. Berdasarkan penelitian yang dilakukan beberapa peneliti tersebut diatas, maka dapat ditarik suatu hipotesis, yaitu :

H1 : Kelengkapan disclosure berpengaruh positif terhadap volume perdagangan saham.

\subsection{Pengaruh ketepatan waktu pengungkapan terhadap Trading volume activity (TVA)}

Pengungkapan informasi yang berkualitas tentunya tidak hanya dilihat dari pengungkapan wajib dan sukarela saja, namun waktu pengungkapan menjadi suatu indikator untuk menentukan kualitas suatu informasi. Ketepatan waktu pelaporan keuangan menunjukkan tingkat relevan suatu informasi (Niarchos dan Georgapoulos, 1986; Haw et al,2000; dalam Septiani,2005). Ketepatan waktu informasi mengindikasikan bahwa informasi yang disampaikan akan memberikan good news sebagai sinyal positif bagi investor, sehingga akan bereaksi pada pasar modal yang mengindikasikan tingkat perdagangan saham 
di pasar saham ikut berpengaruh. Penelitian Chamber dan Penman (1984); Leventis dan Weetman (2004), di pasar modal yang sedang berkembang dengan menggunakan surrogate variabel volume perdagangan dan penerbitan saham publik, hasilnya menunjukkan bahwa volume perdagangan berasosiasi negatif dengan leadtime atau dengan kata lain volume perdagangan saham akan tinggi jika keterlambatan pengungkapan laporan keuangan yang rendah atau menunjukkan adanya ketepatan waktu yang tinggi. Hasil penelitian terbukti sesuai prediksi Diamond (1985) dan Verrechia $(1983,1990)$. Berdasarkan uraian diatas dapat ditarik suatu hipotesis, yaitu :

H2 : Ketepatan waktu pengungkapan berpengaruh positif terhadap aktivitas volume perdagangan.

\subsection{Pengaruh Kelengkapan disclosure terhadap return saham}

Kualitas pengungkapan yang di ukur berdasarkan kelengkapan disclosure akan memberikan reaksi investor secara positif, sehingga pergerakan harga saham akan naik. Penelitian Brian J. Bushee \& Cristopher F. Noe (2000) menyimpulkan bahwa kualitas pengungkapan yang tinggi mempengaruhi volatility return saham, sehingga return saham berpengaruh secara positif. Penelitian ini sejalan dengan yang dilakukan oleh Medeiros (2003) di Brazil dan Mouselli (2009) di Inggris dalam Anwar (2010), yang menyatakan bahwa kualitas informasi yang di ukur dari tingkat disclosure yang tinggi dapat mempengaruhi return saham. Penelitian Hsiu-i-Ting (2008), menyatakan bahwa disclosure yang lebih baik berdampak pada return saham akan lebih baik, khususnya pada perusahaan yang memiliki informasi spesifik dan stabil. Berdasarkan uraian diatas dapat ditarik suatu hipotesis, yaitu :

H3 : Kelengkapan disclosure berpengaruh positif terhadap return saham.

\subsection{Pengaruh ketepatan waktu pengungkapan terhadap return saham}

Ketepatan waktu penyampaian laporan keuangan merupakan suatu alat yang berpengaruh secara signifikan dalam memprediksi kondisi keuangan suatu perusahaan. Pengungkapan yang tepat waktu akan memberikan informasi yang berguna dan memiliki nilai relevansi yang lebih tinggi, sehingga memberikan manfaat dalam pengambilan keputusan investor. Penjelasan Chamber dan Penman (1984), memberikan bukti deskriptif atas adanya hubungan antara ketepatan waktu pelaporan dengan perilaku harga saham sekitar 
tanggal pengumuman. Penelitian Kross dan Schoeder (1984) dalam Jaswadi (2004) melakukan pengujian asosiasi antara pengumuman laba kuartalan (lebih awal dan terlambat) dan tipe laporan serta hubungan antara return saham dan timing pengumuman laba dengan memperbaiki model Givoly dan Palmon (1982), hasilnya menunjukkan bahwa timing pengumuman laba berasosiasi dengan return abnormal sekitar tanggal pengumuman laba. Penelitian Priyastiwi (2000) dalam Jaswadi (2004) menemukan adanya hubungan antara variabel ketepatan waktu laporan keuangan dengan harga saham dan membuktikan pola ketetapatan waktu pelaporan di reaksi pasar modal dan penyampaian laporan keuangan lebih awal akan dianggap sebagai good news dan terlambat sebagai bad news. Berdasarkan uraian diatas dapat ditarik suatu hipotesis, yaitu :

H4 : Ketepatan waktu pengungkapan berpengaruh positif terhadap return saham.

\section{METODOLOGI PENELITIAN}

\subsection{Jenis dan Sumber Data}

Jenis data yang digunakan dalam penelitian ini adalah data sekunder dan sumber data yang digunakan adalah : Annual report perusahaan yang diambil dari perusahaan listed di bursa efek yang terdaftar dalam LQ-45, volume perdagangan saham harian dan pergerakan harga saham/harga saham untuk data tahun 2008 - 2011.

\subsection{Populasi dan Sampel}

Populasi yang digunakan dalam penelitian ini adalah semua perusahaan yang masuk dalam indeks LQ-45 di Bursa Efek Indonesia (BEI). Teknik pengambilan sampel menggunakan purposive sampling, yang berarti bahwa populasi yang akan di jadikan sampel penelitian adalah populasi yang memenuhi kriteria sampel tertentu sesuai dengan yang dikehendaki peneliti, yaitu (1) Saham perusahaan yang aktif dari tahun 2008 sampai dengan tahun 2011.(2) Perusahaan yang memperoleh laba dari tahun 2008 sampai dengan tahun 2011. (3) perusahaan yang tidak mengalami confounding effect yaitu faktor pengganggu dalam periode pengamatan dengan adanya pembagian deviden dan stock plit. 


\subsection{Metode pengumpulan data}

Data yang digunakan dalam penelitian ini dikumpulkan dari beberapa sumber antara lain: PDBE UGM ,BEI, Yahoo Finance dan Bapepam. Data yang digunakan merupakan gabungan data antara perusahaan (cross section) dan antar waktu (time series) atau dikenal dengan pooled cross section-time series atau data panel dengan jumlah sampel 27 (dua puluh tujuh) perusahaan selama 4 (empat) tahun.

\subsection{Definisi Operasional Variabel}

\section{Trading Volume Activity (TVA)}

Digunakan dengan memproxikan pada Unexpected Trading Volume yang merupakan cerminan kejutan dalam reaksi pasar terhadap sebuah informasi yang memiliki nilai (Bamber, 1986).

Pengukuran Unexpected Trading Volume dilakukan dengan membandingkan antara median trading volume activity (TVA) selama periode normal dengan median trading volume activity (TVA) selama periode pengamatan sebagaimana penelitian Wahyuningsih (2004). Volume perdagangan saham / TVA merupakan suatu pengukuran apakah pengumuman yang dikeluarkan perusahaan berhubungan dengan kenaikan volume aktivitas perdagangan saham perusahaan yang bersangkutan pada saat pengumuman tersebut (Bamber,1986). Pengukuran TVA menurut Foster (1986)

$\sum$ saham perusahaan $\mathrm{J}$ yang diperdagangkan pada waktu $\mathrm{t}$ TVA $=$

$\sum$ Saham perusahaan J yang beredar pada waktu $\mathrm{t}$

\section{Return Saham}

Digunakan dengan memproxikan pada Cumulative abnormal return (CAR) yang di hitung dalam jendela amatan 11 (sebelas) hari, terdiri dari 5 (lima) hari sebelum pengungkapan dan 5 (lima) hari setelah pengungkapan. Perhitungan abnormal returnnya menggunakan mean adjusted model (model sesuaian rerata). Model ini menganggap bahwa return ekspektasian bernilai konstan yang sama dengan rerata return realisasian sebelumnya selama periode estimasi (Jogiyanto,2010;73). Abnormal return (ARit) diperoleh melalui dua 
tahap, yaitu tahap pertama merupakan selisih dari return actual $\left(\mathrm{R}_{\mathrm{i}, \mathrm{t}}\right)$ yang kemudian di kurangi dengan return ekspektasi $\mathrm{E}(\mathrm{Ri}, \mathrm{t})$ yang diperoleh dari tahap kedua:

$$
\begin{aligned}
& \mathbf{A R}_{\mathrm{it}}=\mathbf{R}_{\mathrm{it}}-\mathbf{E}\left(\mathbf{R}_{\mathrm{i}, \mathrm{t}}\right) \\
& \mathbf{R}_{\mathrm{it}}=\underline{\left(\mathbf{I H S I}_{\mathrm{t}}\right)-\left(\mathbf{I H S I}_{\mathrm{t}-1}\right)}
\end{aligned}
$$

$\left(\right.$ IHSI $\left._{t-\mathbf{i}}\right)$

Keterangan :

$\mathrm{AR}_{\mathrm{it}} \quad=$ Abnormal return untuk sekuritas ke-I pada hari ke-t

$\mathrm{R}_{\mathrm{it}} \quad=$ Return untuk sekuritas ke-I pada hari ke- $\mathrm{t}$

$\mathrm{E}(\mathrm{Ri}, \mathrm{t})=$ Return Ekspektasi perusahaan ke-I pada periode estimasi

IHSI = Indeks Harga saham individu/ perusahaan sampel.

Return ekspektasi berdasarkan periode estimasi 200 (dua ratus) hari di hitung dari 5 (lima) hari sebelum adanya pengungkapan informasi, yaitu :

$$
\mathbf{E}(\mathbf{R i}, \mathbf{t})=\frac{\sum^{J=-6}}{200}
$$

Cumulatif Abnormal Return (CAR) di hitung selama 5 (lima) hari sebelum pengungkapan dan 5 (lima) hari setelah pengungkapan dengan formulasi sebagai berikut

$$
\mathrm{CAR}_{\mathrm{it}}=\mathrm{CAR}_{\mathrm{it}(-5,+5)}=\stackrel{+5}{=} \mathrm{ARit}
$$

$-5$

Keterangan :

$\mathrm{CAR}_{\mathrm{it}(-5,+5)}=$ return abnormal kumulatif perusahaan I selama periode amatan yaitu 5 hari sebelum dan sesudah pengungkapan informasi 


\section{Kelengkapan Disclosure}

Yaitu terdiri dari pengungkapan wajib dan pengungkapan sukarela yang diukur dengan menggunakan indeks kelengkapan disclosure laporan keuangan, dengan rumus index Wallace menurut (Nugraheni, 2002) adalah:

$$
\text { Index Wallace }=\underline{\mathrm{n}} \times 100 \%
$$

$\mathrm{K}$

Pengukuran indeks dilakukan dengan 86 item pengungkapan, menurut Peraturan Bapepam yaitu X.K.6 (tahun 2006) yang merupakan pengungkapan wajib dan pengungkapan sukarela yang bersumber dari KNKG (2006) dan penelitian Joko susanto (1992); dalam Sutomo (2004).

\section{Ketepatan waktu}

Dalam penyampaian laporan keuangan ini diukur dengan cara kebijakan penundaan (Discretionary Delay) sebagaimana dilakukan oleh Leventis dan Weetman (2004), Septiani (2005) serta Wirakusuma (2008) dengan menggunakan proporsi waktu yang digunakan manajemen untuk menunda pelaporan keuangan kepada public setelah ditandatanganinya laporan audit, dengan pengukuran $=\quad \mathrm{b} / \mathrm{b}+\mathrm{c}$

dimana proporsi waktu penyampaian laporan keuangan terlihat dari gambar sebagai berikut :

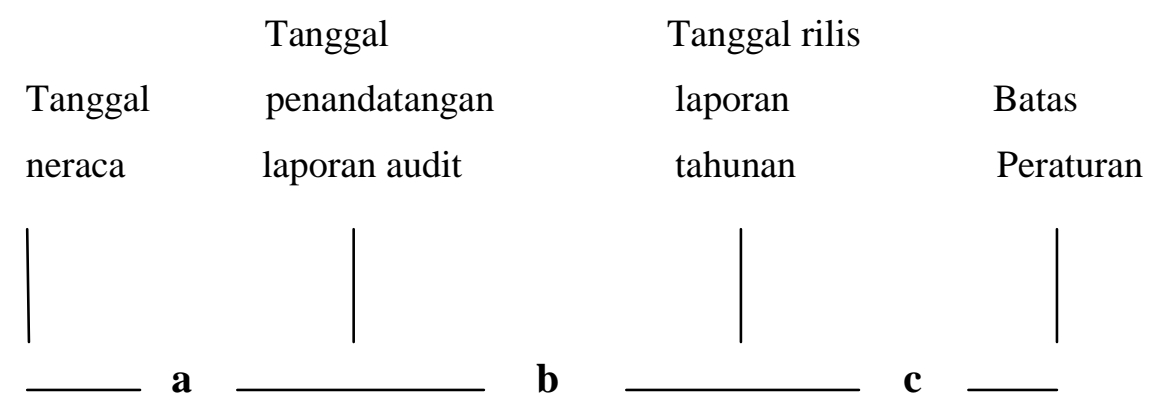

Keterangan:

$\mathbf{a}=$ waktu diantara tanggal neraca dengan tanggal penandatanganan laporan audit

b = waktu diantara tanggal penandatanganan laporan audit dengan tanggal rilis

c = waktu diantara tanggal rilis dan batas peraturan

$\mathbf{b}+\mathbf{c}=$ waktu yang tersedia untuk merilis laporan

$\mathbf{a}+\mathbf{b}=$ dari waktu tunggu (lead time) pengungkapan 


\subsection{Variabel Control}

Pada model 2 untuk mengukur return saham digunakan Profitabilitas sebagai variabel control agar hasil dari pengaruh variabel independen dengan memasukkan profitabilitas akan berpengaruh secara kuat terhadap variabel dependen yaitu return saham. Sesuai dengan penelitian dikemukakan oleh Sunarto (2001) dan Hardiningsih (2002) serta Suhairy (2006) yang diuji kembali oleh Hidayat (2009) menunjukkan bahwa tingkat profitabilitas berpengaruh positif terhadap return saham khususnya pada pengukuran dengan menggunakan ROA.

Penelitian ini menggunakan model analisis linear regresi berganda (multiple regression). Metode ini digunakan untuk mengetahui pengaruh variabel independen, berupa kelengkapan disclosure dan ketepatan waktu terhadap variabel dependen, yaitu aktivitas volume perdagangan saham dan return saham, sebagai berikut :

$$
\begin{aligned}
& \text { UETVA }=\beta_{0}+\beta_{1} \mathrm{KLKP}_{1}+\beta_{2} \mathrm{KTPW}_{2}+\varepsilon \ldots \ldots \ldots \\
& \mathrm{CAR}=\beta_{0}+\beta_{1} \mathrm{KLKP}_{1}+\beta_{2} \mathrm{KTPW}_{2}+\beta_{3} \mathrm{ROA}_{3}+\varepsilon
\end{aligned}
$$

Keterangan:

$$
\begin{array}{ll}
\text { UETVA } & =\text { Unexpected Trading Volume } \\
\mathrm{CAR} & =\text { Cumulatif Abnormal Return } \\
\beta_{\mathrm{O}} & =\text { Konstanta } \\
\beta_{1}, \beta_{2}, \beta_{3} & =\text { Koefisien regresi } \\
\mathrm{KLKP}_{1} & =\text { Kelengkapan disclosure } \\
\mathrm{KTPW}_{2} & =\text { Ketepatan waktu } \\
\mathrm{ROA}_{3} & =\text { Return On Asset (Variabel control dari Profitabilitas) }
\end{array}
$$

\subsection{Metode Analisis Data}

Terdapat empat pengujian yang digunakan untuk melakukan uji asumsi klasik, yaitu Uji Multikolinearitas, Uji Heteroskedastisitas dan Uji Autokorelasi serta uji Statistik dengan Uji Normalitas. Keempat pengujian tersebut di analisis menggunakan program eviews 4.dan Uji koefisien determinan, uji statistik F- test dan uji T-test pada tingkat signifikan 0.05 


\section{HASIL DAN PEMBAHASAN}

\subsection{Kelengkapan Disclosure}

Kelengkapan disclosure yang terdiri dari pengungkapan wajib dan pengungkapan sukarela selama 4 (empat) tahun ditunjukkan pada tabel 4.1 sebagai berikut :

Tabel 4.1

Kelengkapan Disclosure

\begin{tabular}{|l|l|l|l|l|}
\hline Keterangan & $\begin{array}{l}\text { Tahun } \\
\mathbf{2 0 0 8}\end{array}$ & $\begin{array}{l}\text { Tahun } \\
\mathbf{2 0 0 9}\end{array}$ & $\begin{array}{l}\text { Tahun } \\
\mathbf{2 0 1 0}\end{array}$ & $\begin{array}{l}\text { Tahun } \\
\mathbf{2 0 1 1}\end{array}$ \\
\hline Rata-rata KLKP (\%) & $66.11 \%$ & $70.63 \%$ & $72.37 \%$ & $73.52 \%$ \\
\hline Standar Deviasi & 0.083543 & 0.091867 & 0.082562 & 0.083683 \\
\hline Maximum & 0.81 & 0.83 & 0.84 & 0.84 \\
\hline Minimum & 0.53 & 0.53 & 0.55 & 0.55 \\
\hline
\end{tabular}

Berdasarkan tabel 4.1 diatas diperoleh rata-rata kelengkapan disclosure tahun 2008 dengan rata-rata rasio sebesar $66.11 \%$ dan tahun 2011 rata-rata rasio sebesar $73.5 \%$. Hasil ini menunjukkan adanya peningkatan disclosure dari tahun ke tahun Hal ini berarti adanya kesadaran manajemen perusahaan dalam mengungkapkan informasi keuangan dan non keuangannya, serta semakin tinggi tingkat ketaatan perusahaan terhadap kebijakan yang dibuat oleh Bapepam.

\subsection{Ketepatan Waktu}

Ketepatan waktu berdasarkan jumlah hari penundaan publikasi setelah pengauditan ditunjukkan pada tabel 4.2 sebagai berikut :

Tabel 4.2

\section{Ketepatan Waktu Pengungkapan}

\begin{tabular}{|l|l|l|l|l|}
\hline Keterangan & $\begin{array}{l}\text { Tahun } \\
\mathbf{2 0 0 8}\end{array}$ & $\begin{array}{l}\text { Tahun } \\
\mathbf{2 0 0 9}\end{array}$ & $\begin{array}{l}\text { Tahun } \\
\mathbf{2 0 1 0}\end{array}$ & $\begin{array}{l}\text { Tahun } \\
\mathbf{2 0 1 1}\end{array}$ \\
\hline Rata-rata KTPW (\%) & $32.72 \%$ & $23.28 \%$ & $23.62 \%$ & $24.22 \%$ \\
\hline Standar Deviasi & 0.277936 & 0.160566 & 0.224798 & 0.225379 \\
\hline Maximum & 1 & 0.57 & 0.97 & 1 \\
\hline Minimum & 0.015 & 0.015 & 0.015 & 0 \\
\hline
\end{tabular}

Sumber : Data diolah, tahun 2012 
Tabel 4.2 menunjukkan bahwa perusahaan telah menyampaikan publikasi laporan keuangan sesuai ketentuan yang ditentukan oleh Bapepam sampai batas waktu 120 hari. Semakin cepat penyampaian laporan keuangan tahunan setelah audit maka memiliki nilai ratio yang rendah.

\subsection{Analisis Deskriptif}

Tabel 4.3

Statistik Deskripsi

\begin{tabular}{|l|l|l|l|l|l|}
\hline & UETVA & CAR & KLKP & KTPW & ROA \\
\hline Mean & 0.012725 & 0.111731 & 0.706574 & 0.258778 & 0.129497 \\
\hline Median & 0.015247 & 0.108167 & 0.730000 & 0.200000 & 0.116500 \\
\hline Maximum & 0.535392 & 0.186783 & 0.840000 & 1.000000 & 0.407000 \\
\hline Minimum & -0.568838 & 0.020191 & 0.530000 & 0.000000 & 0.009000 \\
\hline Std. Dev. & 0.221319 & 0.027461 & 0.088920 & 0.226602 & 0.100958 \\
\hline Observations & 108 & 108 & 108 & 108 & 108 \\
\hline Cross sections & 27 & 27 & 27 & 27 & 27 \\
\hline
\end{tabular}

Sumber : data diolah (Eviews), tahun 2013

Tabel 4.3 merupakan deskripsi keseluruhan variabel penelitian berdasarkan output eviews secara pooled data sebanyak 108 observasi yang mencakup nilai rata-rata, maksimum, minimum dan standar deviasi.

\subsection{Analisis Uji Hipotesis}

Pengujian hipotesis dilakukan menggunakan persamaan Regresi Linear berganda, namun untuk memenuhi syarat suatu persamaan regresi terlebih dahulu dilakukan uji asumsi klasik sebagai berikut : 


\section{Uji Normalitas Data}

Tabel 4.4

Hasil Uji Normalitas

\begin{tabular}{|l|l|l|l|l|l|}
\hline Uji Kolmogorov-Smirnov (K-S) *) \\
\hline Variabel & $\begin{array}{l}\text { UETVA } \\
\text { LOG }\end{array}$ & CAR LOG & KLKP & KTPW & ROA \\
\hline Kolmogorov-Smirnov Z & .825 & .624 & 1.176 & 1.572 & 1.489 \\
\hline Asymp. Sig. (2-tailed) & .504 & .831 & .126 & .014 & .024 \\
\hline Uji Jarque-Bera $* *)$ & 0.360684 & 7.428182 & 7.016643 & 53.92879 & 15.26470 \\
\hline Jarque-Bera & 0.834985 & 0.024378 & 0.029947 & 0.000000 & 0.000485 \\
\hline Probability &
\end{tabular}

Sumber : data diolah $*$ ) Output SPSS dan

**) Output Eviews, tahun 2013

Dari tabel 4.4 terlihat hasil uji normalitas yang digunakan dalam penelitian ini adalah uji Kolmogorov-Smirnov dan Jarque-Bera. Uji Kolmogorov-Smirnov (output SPSS), memiliki distribusi normal jika nilai Asymp.Sig (2-tailed) > 0.05. Hasil tersebut menunjukkan bahwa variabel yang memiliki distribusi normal adalah CAR setelah ditranformasi sebesar 0.83, KLKP (Kelengkapan disclosure) sebesar 0.126 dan UETVA (Unexpected Trading Volume) setelah ditransformasi sebesar 0.504. Sedangkan KTPW (ketepatan Waktu) dan ROA tidak berdistribusi normal. Pada Jarque-Bera (output Eviews) memiliki distribusi normal jika nilai probability > 0.05. Pada tabel 4.4 menunjukkan bahwa yang memiliki probability > 0.05 hanya pada variabel UETVA. Sedangkan CAR, KLKP, KTPW dan ROA memiliki nilai $\mathrm{p}<0.05$ yang berarti data tidak berdistribusi normal. Penelitian ini di asumsikan mendekati normal dengan menggunakan dasar asumsi distribusi normal (central limit Theoreme) yang menyatakan bahwa distribusi sampel dapat dikatakan mendekati normal apabila ukuran sampel yang diperoleh cukup besar (Neter,et.al, 1993:267). Penelitian Mendenhall dan Beaver yang dikutip Restuningdiah dan Indriantoro (1999) dalam Wirakusuma (2008) menjelaskan hal yang sama dengan menyatakan bahwa dengan menetapkan jumlah minimum 100 sampel, maka dapat digunakan untuk pengujian statistik parametrik. 
Tabel 4.5

Hasil Uji Asumsi Klasik

\begin{tabular}{|l|l|l|l|l|}
\hline \multirow{2}{*}{ Asumsi Klasik } & \multicolumn{2}{|l|}{ Model 1 } & \multicolumn{2}{l|}{ Model 2 } \\
\hline Uji Multikolinieritas & VIF & TOC & VIF & TOC \\
\cline { 2 - 5 } & 4.399 & 0.277 & 4.44 & 0.225 \\
\cline { 2 - 5 } & 4.618 & 0.216 & 1.579 & 0.633 \\
\cline { 2 - 5 } & & & 8.77 & 0.114 \\
\hline Uji Heterokesdatistas & $\begin{array}{l}\text { Sum square } \\
\text { Weighted } \\
\text { Statistic }\end{array}$ & $\begin{array}{l}\text { Sum square } \\
\text { UnWeighted } \\
\text { Statistic }\end{array}$ & $\begin{array}{l}\text { Sum square } \\
\text { Weighted } \\
\text { Statistic }\end{array}$ & $\begin{array}{l}\text { Sum square } \\
\text { UnWeighted } \\
\text { Statistic }\end{array}$ \\
\cline { 2 - 5 } & 3.951628 & 3.977851 & 0.066215 & 0.066674 \\
\hline Uji Autokorelasi & Durbin Witson(DW) & Durbin Witson (DW) \\
\cline { 2 - 5 } & 2.371495 & \multicolumn{3}{|l}{} \\
\hline
\end{tabular}

Sumber: data diolah dari Output eviews, tahun 2013

Dalam pengujian multikolinieritas dengan menggunakan metode Variance Inflation Factor (VIF) dan Tolerance (TOC) dari regresi auxiliary antara variabel independen menunjukkan, bahwa pada persamaan model 1 dan model 2 tidak ada multikolinearitas.Pengujian heteroskedastisitas dalam penelitian ini menggunakan uji white heteroskedastisitas yang dilakukan secara langsung dalam persamaan model. Hasil pengujian terlihat juga dari tabel 4.5 menunjukkan bahwa pada model 1dan 2 tidak mengandung unsur heteroskedastisitas dengan nilai Sum Squared Resid Weighted statistik lebih rendah dari Sum Squared Resid Unweighted statistik $(3.951628<3.977851)$ pada model 1dan model $2(0.066215<0.066674)$. Pada pengujian autokorelasi, peneliti menggunakan uji Durbin-Watson yang menunjukkan apabila nilai d berada di antara 1.54 dan 2.46, maka tidak terdapat adanya autokorelasi. Hasil penelitian terlihat dari tabel 4.5 menunjukkan bahwa pada model 1 dan model 2 nilai uji Durbin-Watson (DW) sebesar 2.37 dan 2.31, sehingga dinyatakan bahwa tidak terdapat adanya autokorelasi. 


\section{Hasil Uji Persamaan model}

Tabel 4.6

\section{Hasil Pengujian Persamaan Regresi Model 1dan 2}

\begin{tabular}{|l|l|l|}
\hline & Model 1 & Model 2 \\
\hline $\mathrm{R}^{2}$ & & \\
Adjusted R-Squared & 0.370531 & 0.969736 \\
F stat & 0.147428 & 0.958485 \\
Prob (F-stat) & 1.660808 & 86.18481 \\
& 0.041614 & 0.00000 \\
& $\alpha<0.05$ & $\alpha<0.05$ \\
\hline
\end{tabular}

Berdasarkan tabel 4.6 diatas menunjukkan nilai $R$-square pada model 1 sebesar 0,37 yang mencerminkan bahwa UETVA(Unexpected Trading Volume) sebagai variabel dependent dapat dijelaskan oleh variabel independent yaitu KLKP(kelengkapan disclosure) dan KTPW(ketepatan waktu) sebesar $37 \%$ dengan tingkat probabilitas F- Statistik sebesar 0,0416 dengan tingkat signifikan $<0.05$. Hasil nilai ini mencerminkan bahwa model yang diuji layak untuk menunjukkan hubungan antara variabel dependen dan variabel independen. Dari persamaan regresi model 2 memiliki $R$-square sebesar 0,96 yang mencerminkan bahwa CAR (Cumulative Abnormal Return) sebagai variabel dependent dapat dijelaskan oleh variabel independen yaitu KLKP (Kelengkapan disclosure), KTPW(Ketepatan waktu) dengan variabel control ROA sebesar 96\% dengan tingkat probabilitas F- statistic 0.0000. Hasil ini mencerminkan bahwa model yang diuji layak dalam menunjukkan hubungan antara variabel dependen dengan variabel independen.

\section{Uji Hipotesis 1}

Tabel 4.7

Hasil uji Hipotesis 1

\begin{tabular}{|l|l|l|l|}
\hline variabel & koefisient & t-stat & Prob \\
\hline KLKP & 0.30915 & 2.701437 & 0.0084 \\
\hline \multicolumn{4}{|l}{ Sign $=\alpha<0.05$} \\
\hline
\end{tabular}

Sumber: data olah eviews (fixed effect), 2013 
Berdasarkan hasil pengujian tabel 4.7 dapat menjawab hasil hipotesis 1 yang menyatakan bahwa ada pengaruh kelengkapan disclosure terhadap aktivitas volume perdagangan saham dengan nilai probabilitas $<0,05$ atau probabilitas sebesar 0.0084 dengan koefisien 0,309, berarti setiap perubahan kelengkapan disclosure 1persen akan meningkatkan volume perdagangan yang diharapkan meningkat sebesar 30.9 persen, dengan demikian hipotesis 1 terbukti menunjukkan adanya pengaruh positif yang signifikan.

Berdasarkan uji hipotesis menunjukkan bahwa hasil penelitian ini mendukung teori peneliti sebelumnya, yang dilakukan oleh Kim and Verrecchia (1991), frank Heflin, Brian J. Bushee, Cristofer F. Noe (1999),Wysocki (2000) , Michael Grunning (2011) dan penelitian Junaedi (2005). Hal ini mengindikasikan bahwa dengan semakin lengkap disclosure memberikan tingkat informasi yang berkualitas, dengan tingkat informasi yang berkualitas memberikan suatu sinyal bagi investor dalam mengambil suatu keputusan dalam berinvestasi, sehingga memberikan reaksi investor yang dapat menyebabkan pergerakan volume perdagangan saham di pasar bursa menjadi meningkat. Pernyataan ini sesuai dengan hasil penelitian Junaedi (2005) yang terjadi pada kondisi pasar modal Indonesia dengan pertumbuhan ekonomi yang relative stabil. Hal ini mengindikasikan bahwa kualitas pengungkapan informasi berdasarkan tingkat pergerakan volume perdagangan saham di pasar modal Indonesia baik dalam kondisi normal maupun dipengaruhi oleh keadaan krisis perekonomian secara global menunjukkan pengaruh positif terhadap pergerakan volume perdagangan saham.

Hasil dari hipotesis ini berimplikasi bahwa kelengkapan disclosure memberikan bukti adanya suatu informasi yang berkualitas. Kualitas informasi yang lebih tinggi memberikan suatu sinyal bagi investor dalam pengambilan keputusan untuk berinvestasi. .

\section{Uji Hipotesis 2}

\section{Tabel 4.8}

\section{Hasil uji Hipotesis 2}

\begin{tabular}{|l|l|l|l|}
\hline variabel & koefisient & t-stat & Prob \\
\hline KTPW & -0.024382 & -0.96554 & 0.3372 \\
\hline Sign= $\alpha<0.05$
\end{tabular}

Sumber: data olah eviews (fixed effect), 2013 
Pengujian hipotesis 2 menyatakan bahwa ada pengaruh positif ketepatan waktu terhadap aktivitas volume perdagangan saham. Berdasarkan hasil yang terlihat pada tabel 4.8 menunjukkan bahwa ketepatan waktu tidak berpengaruh terhadap aktivitas perdagangan saham. Hal ini dapat dilihat pada probabilitas sebesar 0,337 yang lebih besar dari tingkat signifikan sebesar 0.05. Hasil ini menunjukkan bahwa hipotesis 2 tidak terbukti bahwa ketepatan waktu berpengaruh positif terhadap aktivitas volume perdagangan saham.

Hasil penelitian ini tidak sesuai dengan justifikasi Scott(1994) dan Leventis dan Weetman (2004) yang menyatakan bahwa tingkat volume perdagangan saham yang relatif tinggi akan memfokuskan untuk mengurangi biaya informasi bagi para pemegang saham melalui pengungkapan yang tepat waktu atau dengan kata lain pengungkapan informasi yang semakin lebih cepat / tepat akan memberikan tingkat pergerakan volume perdagangan saham yang tinggi. Penelitian Septiani (2005) menyatakan bahwa volume perdagangan saham yang tinggi tidak dipengaruhi oleh ketepatan waktu pengungkapan laporan keuangan pada pasar modal yang sedang berkembang khususnya pada pasar modal Indonesia (PT. Bursa Efek Indonesia) yang sesuai dengan hasil penelitian ini.

Implikasi dari penelitian ini memberikan bukti bahwa ketepatan waktu tidak berpengaruh terhadap volume perdagangan saham dipasar modal yang sedang berkembang, hal ini mengindikasikan bahwa kondisi pasar modal Indonesia masih memiliki karakteristik sebagai pasar modal yang setengah kuat (semi strong) karena masih banyak investor melihat ketepatan waktu pengungkapan belum merupakan suatu petunjuk adanya penyampaian informasi/ berita yang baik (Good news), sehingga naik turunnya volume perdagangan saham bukan disebabkan oleh adanya ketepatan waktu pengungkapan laporan keuangan.

\section{Uji Hipotesis 3}

\section{Tabel 4.9}

\section{Hasil uji Hipotesis 3}

\begin{tabular}{|c|l|l|l|}
\hline variabel & koefisient & t-stat & Prob \\
\hline KLKP & -0.122142 & -4.477009 & 0.0000 \\
\hline \multicolumn{5}{|l|}{ Sign $=\alpha<0.05$} \\
S
\end{tabular}

Sumber: data olah eviews (fixed effect), 2013

Pengujian hipotesis ke-3 dengan menambahkan variabel control ROA, untuk melihat apakah kelengkapan disclosure berpengaruh positif terhadap return saham. Berdasarkan 
tabel 4.9 dibuktikan bahwa kelengkapan disclosure memiliki nilai probability 0,000 dan koefisien sebesar - 0,122 yang berarti setiap perubahan kelengkapan disclosure sebesar 1 persen menyebabkan terjadinya penurunan terhadap nilai return saham sebesar 12,2 persen. Hasil ini menunjukkan bahwa kelengkapan disclosure berpengaruh negative terhadap return saham yang diharapkan, dengan demikian hipotesis ke-2 tidak terbukti bahwa kelengkapan disclosure berpengaruh positif terhadap return saham.

Hasil ini menunjukkan semakin lengkap disclosure, return saham diharapkan semakin rendah, sehingga mengindikasikan investor sangat sedikit menggunakan informasi yang terdapat dalam pengungkapan informasi annual report sebagai dasar untuk pengambilan keputusan. Hasil penelitian tidak mendukung dengan penelitian yang dilakukan oleh Medeiros (2003) dan Mouselli (2009), namun sesuai dengan penelitian Junaedi (2005), Restuningdiah (2010) menyatakan bahwa disclosure bernilai negatif terhadap abnormal return dan penelitian EFS, Viera (2011) menyatakan semakin tinggi disclosure (pengungkapan) semakin rendah volatilitas harga saham.

Penelitian ini memberikan suatu implikasi bahwa kelengkapan disclosure yang merupakan cerminan kualitas informasi belum merupakan suatu informasi yang berperan penting dalam menentukan keputusan investor pada pelaku pasar di bursa efek Indonesia khususnya pada kondisi krisis global . Kelengkapan disclosure menjadi suatu informasi yang berarti, untuk itu bagi para manajer perusahaan perlu mempertimbangkan setiap item disclosure (pengungkapan) dalam annual report khususnya pengungkapan sukarela agar memberikan suatu informasi yang memiliki nilai yang sangat bermanfaat bagi pelaku pasar dalam menentukan keputusan investasinya.

\section{Uji Hipotesis 4}

Tabel 4.10

\section{Hasil uji Hipotesis 4}

\begin{tabular}{|l|l|l|l|}
\hline variabel & koefisient & t-stat & Prob \\
\hline KTPW & 0.015122 & 2.115454 & 0.0376 \\
\hline ROA & 0.070797 & 14.47616 & 0.0000 \\
\hline \multicolumn{4}{|l}{ Sign $=\alpha<0.05$}
\end{tabular}

Sumber: data olah eviews (fixed effect), 2013 
Pada hipotesis 4 untuk melihat apakah ketepatan waktu berpengaruh terhadap return saham terutama dikaitkan dengan variabel control ROA. Hasil perhitungan pada tabel 4.10 menunjukkan bahwa ketepatan waktu memiliki probabilitas 0,0376, berarti signifikan pada tingkat 5\% atau 0,05 yang menunjukkan nilai signifikan nya lebih kecil dari 0.05. Nilai koefisien sebesar 0,015 yang berarti ketepatan waktu memiliki nilai 1 persen akan menaikkan return saham yang diharapkan meningkat sebesar 1,5 persen. Berdasarkan hasil tersebut, maka hipotesis ke 4 terbukti bahwa ketepatan waktu pengungkapan berpengaruh positif terhadap return saham yang diharapkan.

Hasil hipotesis 4 yang terlihat dari ketepatan waktu terhadap return saham menunjukkan hasil yang mendukung teori yang dilakukan Krosss dan Schroeder (1984) yang menyatakan bahwa timing pengumuman laba berhubungan dengan return abnormal, Priyastiwi (2000) dalam Jaswadi (2004) yang menyatakan bahwa pelaporan yang lebih awal /cepat di reaksi oleh pasar karena dianggap sebagai good news dan Wirakusuma (2008) yang menyatakan adanya penundaan publikasi laporan keuangan setelah diaudit menurunkan kandungan kualitas informasi serta semakin cepat publikasi laporan keuangan setelah audit dibandingkan dengan dalam masa batas regulasi ketepatan waktu memiliki kandungan kualitas informasi yang lebih baik. Hasil ini mengindikasikan bahwa semakin tepat waktu mengungkapan informasi keuangan dan non keuangan setelah diaudit memiliki kandungan informasi yang berarti dan memberikan sinyal yang baik (Good news) bagi investor. Disamping itu juga ketepatan waktu memberikan informasi yang sangat bermanfaat karena memiliki tingkat relevansi dan keandalan informasi, sekaligus mencerminkan peningkatan kinerja manajemen yang berkesinambungan, sehingga investor akan bereaksi yang akhirnya return saham diharapkan akan tinggi.

Hasil penelitian ini juga berimplikasi bahwa publikasi laporan keuangan yang semakin cepat setelah audit dan adanya tingkat laba yang baik menunjukkan suatu berita baik (goodnews), akhirnya memberikan respon positif bagi investor dan sebagian para pelaku pasar akan cepat bereaksi terhadap informasi pengungkapan dan publikasi laporan keuangan.

Pada persamaan regresi model 2 yang menjawab hipotesis 3 dan hipotesis 4 menggunakan variabel ROA sebagai variabel kontrol yang memberikan pengaruh yang kuat terhadap return saham yang diharapkan, terbukti dari hasil penelitian yang menunjukkan nilai koefisien sebesar $0.071(7.1 \%)$ yang berarti kenaikan 1 persen ROA berpengaruh 
terhadap return saham naik sebesar 7.1 persen dan ini sesuai penelitian yang dikemukakan oleh Sunarto (2001), Suhairy(2006) dan Hidayat (2009). Penelitian ini mengindikasikan bahwa pada model 2 tersebut dengan profitabilitas yang tinggi akan memberikan tingkat return saham yang diharapkan akan meningkat.

\section{SIMPULAN DAN SARAN}

\subsection{Kesimpulan}

Berdasarkan hasil pembahasan yang peneliti lakukan, dapat diambil simpulan sebagai berikut :

1. Berdasarkan persamaan regresi model 1 dan model 2 menunjukkan bahwa adanya kesesuaian model, yaitu kualitas pengungkapan informasi yang tercermin pada laporan tahunan berpengaruh signifikan terhadap aktivitas volume perdagangan saham dan return saham.

2. Kualitas pengungkapan informasi berpengaruh terhadap volume perdagangan saham dilihat dari kelengkapan disclosure menunjukkan hasil signifikan positif, sedangkan pada ketepatan waktu tidak berpengaruh terhadap volume perdagangan saham. Kualitas pengungkapan informasi berpengaruh terhadap return saham yang dilihat dari kelengkapan disclosure tidak berpengaruh positif terhadap return saham, sedangkan ketepatan waktu berpengaruh signifikan terhadap return saham.

3. Secara keseluruhan kedua model persamaan regresi menunjukkan hasil kualitas pengungkapan informasi belum memberikan pengaruh yang besar terhadap aktivitas volume perdagangan saham dan return saham, sehingga informasi yang dihasilkan dari annual report belum sebagai salah satu sumber informasi yang terpenting dalam menentukan pengambilan keputusan investasi para investor, khususnya dalam konteks krisis global.

\subsection{Saran}

Pada penelitian ini masih banyak keterbatasan yang dilakukan oleh peneliti yaitu:

1. Penelitian ini tidak melihat perilaku investor baik sisi individual maupun corporate sehingga masih adanya variabel yang memiliki data ekstrim dan sampel perusahaan yang sedikit, hal ini menyebabkan adanya data yang tidak berdistribusi normal. Di sarankan 
untuk penelitian lebih lanjut data sampel perusahaan diperbanyak supaya hasil penelitian dapat lebih di generalisasi.

2. Agar hasil penelitian bisa memberikan hasil yang lebih baik, disarankan untuk penelitian lebih lanjut memasukkan variabel control lainnya seperti ROE dan NPM sebagai ukuran tingkat Profitabilitas.

3. Untuk memberikan hasil penelitian yang lebih baik yang dikaitkan dengan krisis global dan berpengaruh terhadap kinerja pasar modal Indonesia, maka sebaiknya untuk penelitian berikutnya harus di tambah variabel-variabel lain dan metode pengukuran yang berbeda khususnya pada kelengkapan disclosure untuk mendukung secara kuat dalam penelitian berikutnya.

\section{DAFTAR PUSTAKA}

Abdul dan Hidayat,N.2000. Studi Empiris Tentang Pengaruh Volume perdagangan dan Return terhadap Bid-Ask Spread Industri Rokok di Bursa Efek Jakarta dengan model Koreksi Kesalahan. Jurnal Riset Akuntansi Indonesia. Vol 3 No.1. Hal 69-85.

Anwar, Arif Budiman. 2010.Analisis Pengaruh Kinerja Keuangan dan Kualitas Pengungkapan Informasi terhadap Return Saham . Universitas Indonesia. http//lontar.ui.ac.id.

Andrian , Harry S. 2010. Pengungkapan Laporan Keuangan,Business \& Accounting. Akuntansi bisnis.Wordpress.com.

2010,2011, Annual Report BEI dan Statistik BEI 2011, www.idx.co.id.

Bushee,Brian J. \& Noe, Christopher F. 2000. Disclosure Quality, Institutional Investors, and Stock Return Volatility,Journal of Accounting Research. JSTOR.

Bandi dan Jogiyanto Hartono. 2000. Perilaku Reaksi Harga dan Volume Perdagangan Saham Terhadap Pengumuman Deviden. Seminar Nasional Akuntansi 2.

Bandi, Hananto \& Tri Santoso . 2000. Ketepatan waktu atas Laporan Keuangan Perusahaan Indonesia. Simposium Nasional Akuntansi II IAI. hal 66 - 75.

Bamber,Linda. 1986. The Information Content of Annual Earnings Announcements: A Trading volume Approach:Jounal of Accounting Research: 40-56. 
Beaver,W.H, 1968, The Information Content of Annual Earning Announcements In Empirical research Accounting: Journal of Accounting Research vol 6 no. 2 pp:67-100.

Boenanto, Dina. November 2011. Krisis Global dan Resiko dalam Perekonomian Indonesia. Vibiz Management Com.:www.vibizconsulting.com.

Brigham, Eugene F, dan Joel F. Houston, 2001. Manajemen Keuangan, Edisi Kedelapan, Erlangga, Jakarta.

Chang,L.S,K.S Most dan CW Brain, 1983, The Utility of Annual Report: An International Business Studies.

Chamber A.E,and Penman,S.H.1984. Timeliness of Reporting and The Stock Price Reaction to Earnings Announcement. Journal of Accounting Research Vol.22 No. 1.

EFS,Viera. 2011.Financial Disclosure and Stock Price Volatility: Evidence from Portugal and Belgium.(Paper).Google Cendikia.

Fanny.2010. Dampak Perekonomian Indonesia Pasca Krisis Ekonomi Global. Artikel Google.id:http://www.google.co.id

Fitriani,Lingga.2007. Disclosure Index laporan Tahunan 2004 Emiten di BEJ,PESAT, Gunadarma, Vol 2 ISSN 1858-2559.

Ghozali, Imam, 2006. Aplikasi Analisis Multivariate dengan Program SPSS, Edisi Ketiga, Badan Penerbit Universitas Diponegoro, Semarang.

Grinning,Michael. 2011. Capital Market Implicaton Of Corporate Disclosure:German Evidence. Bult Business Research official Open Acces Journal of VHB. Volume 4 pp : $48-72$.

Hardiningsih,Pancawati,Suryanto,L Cariri, Anis. 2002. Pengaruh Faktor Fundamental dan Resiko Ekonomi terhadap Return Saham pada Perusahaan di Bursa Efek (Studi kasus Basic Industry \& Chemical). Jurnal Strategi Bisnis. Vol 8. Hal 83 -89.

Heflin,Frank dan Shaw, Kenneth W. 2001. Disclosure Quality and Market Liquidity.(paper). Journal of Law and Economics, October 2005, ISSN 0022-2186.

Hsiu-i-Ting. 2008. Does Corporate Disclosure Quality Help?. International Research Journal Of Finance and Economics. ISSN 1450-2887.

Houlthasen,R.W, and R.E, Verrechia.1990.The Effect Of Sequential Information Releases On The Variance Of Price Change In An Intertemporal Multi Assets.Journal Of Accounting Research 26.Pp: 82-106. 
Hidayat,Taufik. 2009.Pengaruh Rasio Keuangan Terhadap Return Saham pada Perusahaan Yang Terdapat di Bursa Efek.(Thesis).Pasca Sarjana USU.

Hilmi, Utari \&Ali,Syaiful. 2008. Analisis Faktor-faktor Yang Mempengaruhi Ketepatan Waktu Penyampaian Laporan Keuangan (Paper).Seminar Nasional Akuntansi ke XI.Pontianak

Ismail,M.2011. Rasio Leverage,Likuiditas, Profitabilitas dan Porsi Saham Publik terhadap Kelengkapan Pengungkapan Laporan Keuangan pada Perusahaan Pertambangan.Universitas Sumatera Utara.

Jaswadi.2004.Dampak Earning Reporting Lags Terhadap Koefisien Respon Laba,Jurnal Riset Akuntansi Indonesia.Vol.7,No. 3 Pp.295-315.

Junaedi,Dedi. 2005, Dampak Tingkat Pengungkapan Informasi Perusahaan terhadap Volume Perdagangan Saham dan Return Saham. Jurnal Akuntansi dan Keuangan Indonesia. Volume 2. No. 2pp 1-28.

Jenning, R ,1990, A Note on Interpreting Incremental Information Content, The Accounting Review, vol 65, pp 925-932.

Jogiyanto Hartono. 2008. Teori Portofolio dan Analisis Investasi. BPFE Yogyakarta. Edisi Kelima. Yogyakarta.

Jogiyanto Hartono.2005. Salah Kaprah dan Pengalaman-Pengalaman.Metodologi Penelitian Bisnis.BPFE UGM. Hal 157.

Jogiyanto Hartono. 2010. Studi Peristiwa Menguji Reaksi Pasar Modal Akibat Suatu Peristiwa.Edisi Pertama. BPFE UGM. Hal 53.

Karpoff,Jonathan,M.1986. A Theory of Trading Volume.Journal of Finance.Vol XI.1 no. 5.

Kim,O., dan R. Verrecchia. 1991.'Trading volume and price reaction to public announcement'. Journal of Accounting Research 29.(Autumn). . 2009. Krisis Ekonomi Global dan Dampaknya terhadap Perekonomian Indonesia. Outlook Ekonomi Indonesia 2009 -2014. www.BI.Go.id Edisi Januari. Hal 41-67

Leventis,S and Weetman,P.2004.Timeliness of Financial Reporting: Applicability of Disclosure Theories In A Emerging Capital Market. Journal Accounting and Bussiness Research. Vol. 34. No. 1. Pp 43-56.

Munawarah.2009.Analisis Perbandingan Abnormal Return dan Trading Volume Activity Sebelum dan Setelah Suspend BEI.(Tesis). Magister Manajemen Universitas Diponegoro, Semarang. 
Munfaqiroh,Siti. 2006. Pengaruh Publikasi terhadap Volume Perdagangan Saham. Jurnal Media Riset Akuntansi, Auditing \& Informasi. volume 6 . No. 1.

Nugraheni,Yekti L.K, Hartono,Digdo O.,dan Patworo, Harry,P.2002. Analisis Pengaruh Faktor-faktor Fundamental Perusahaan Terhadap Kelengkapan Laporan Keuangan. Jurnal Ekonomi dan Bisnis. Vol VIII. No. 1, hal 75-91.

Nuh,Muhammad. 2008. Memahami Krisis Keuangan Global bagaimana harus bersikap?.Buku 1. Sekretariat Negara.www.Setneg.go.id.

Respati,Tyas,W.N.2001.Faktor-faktor yang berpengaruh terhadap ketepatan waktu pelaporan keuangan.(Thesis).Magister Akuntansi.Universitas Diponegoro.

Restuningdiah,Nurika.2010. Mekanisme GCG dan Pengungkapan Tanggungjawab sosial terhadap Koefisien Respon Laba. Jurnal Keuangan dan Perbankan. Vol 14. No. 3.

Syafruddin,Muchammad.2005.Reaksi Pasar Terhadap Ketepatanwaktuan Penyampaian Laporan Keuangan: Studi di Bursa Efek Jakarta.Jurnal Bisnis dan Akuntansi.Vol. 7. Hal 272-301.

Septiani,Aditya. 2005.Faktor-Faktor yang Mempengaruhi Ketepatan Waktu Pelaporan Keuangan pada Pasar Modal yang Sedang Berkembang: Perspektif Teori Pengungkapan.(Tesis).Magister Sains Akuntansi .Universitas Diponegoro.

Sidauruk, Tagor Daurus .2008. Pengaruh Laporan Arus Kas Terhadap Harga Saham dan Return Saham pada Perusahaan Manufaktur di Bursa Efek.(Tesis). Pasca Sarjana Universitas Sumatera Utara. Medan.

Simanjuntak, Binsar H. dan Widiastuti, Lusy. 2004. Faktor-faktor yang Mempengaruhi Kelengkapan Pengungkapan Laporan Keuangan pada Perusahaan Manufaktur yang Terdaftar di Bursa Efek Jakarta. Jurnal Riset Akuntansi Indonesia. Vol 7 No. 3 .hal 351 -366 .

Suharli,Michell dan Harahap,S,Sofyan. 2008.Timeliness Laporan Keuangan di Indonesia(Studi Empiris Terhadap Emiten Bursa Efek Jakarta).Media Riset Akuntansi,Auditing dan Informasi.Vol 8 No. 2. Hal 97-116.

Sunarto. 2001.Pengaruh Rasio Profitabilitas dan Leverage terhadap Return Saham Perusahaan Manufaktur di BEJ. MGS. Vol 33 no. 3. Hal 63-82.

Sutomo,Ibnu. 2004. Pengaruh Rasio Likuiditas,Solvabilitas,Karakteristik Perusahaan Terhadap Luas Pengungkapan Sukarela pada Laporan Tahunan Perusahaan.(Thesis).Undip___ 2006, Peraturan Nomor X.K.6 : Kewajiban 
Penyampaian Laporan Tahunan Bagi Emiten atau Perusahaan Publik, Bapepam. (http://www.bapepam.go.id/pasar_modal/regulasi_pm/peraturan_pm/index.html

Wahyuningsih, Diah,Rina.2004. Pengaruh Informasi Arus Kas Operasi dan Penyesuaian Akrual Terhadap Unexpected Trading Volume:Studi Empiris di Bursa Efek Jakarta.(Tesis).Undip

Wirakusuma,Made gede. 2008. Pengaruh Ketepatan Waktu Publikasi Laporan Keuangan Terhadap Kandungan Kualitas Informasi Laba Akuntansi di Pasar Modal Indonesia. Jurnal Riset Akuntansi Indonesia. Vol. 11 No. 3 hal 286-311.

Winarno, Wahyu Ning. 2011. Analisis Ekonometrika dan Statistika dengan Eviews.UPP STIM YKPN.Edisi 3. Hal 5.1-5.39.

Wycocki,Peter D. 2000. Private Information, Earnings Announcements and Trading Volume or Stock Chat on the Internet: A Public Debate About Private Information.(Paper). Google Cendikia. 